\title{
A LÉLEK ÖKOLÓGIÁJA: A MŰVÉSZETI NEVELÉS FONTOSSÁGA A 21. SZÁZADBAN
}

\section{ECOLOGY OF THE SOUL: THE NECESSITY OF ART EDUCATION IN THE 21 ${ }^{\text {ST }}$ CENTURY}

\author{
Sanja Krsmanović Tasić \\ drámapedagógus, előadómúvész, a Nemzetközi Drámapedagógiai és Színházpedagógiai Szövetség vezetőségi tagja, \\ a Drámapedagógiai és Múvészeti Központ (CEDEUM) és a Hleb Teatar vezetője \\ sanja.k.tasic@gmail.com
}

\section{ÖSSZEFOGLALÁS}

\begin{abstract}
„Az ökológia és a lélek ökológiája” volt a témája annak az előadó-művészeti projektnek, amelyet az elmúlt három évben drámapedagógiai múhelyek és iskolai drámacsoportok valósítottak meg a szerbiai "Mater Terra” Gyermek és Ifjúsági Színházi Fesztiválokon. „A lélek ökológiája” folyamatos személyiségfejlődést, önmegismerést és a társakkal való együttműködés képességének fejlesztését jelenti. Pedagógiai munkánk egyik fő kérdése: „Meghallgatjuk-e a gyermekeinket?” Konkrétabban: „Meghallgatjuk-e a jövőt?" Hogyan tudnánk felkészíteni őket az olyan kihívásokra és szakmákra, amelyeket még mi magunk sem ismerünk? Az innovatív munkákhoz szükséges képességek az Európai Bizottság 2016-os meghatározása szerint a következők: kritikus gondolkodás, hajlandóság a kutatásra, kérdésfeltevésre és a tervek, ötletek bemutatására. Számomra a színház és a dráma a jövő próbája. A drámatanárokból, előadóművészekből, pszichológusokból álló szakértői csoport a műhelymunkák tapasztalataira alapozva részletes visszajelzést fogalmazott meg a drámapedagógiai alkotó közösségek vezetőinek arról, milyen irányban érdemes továbbfejleszteni csoportjukat. A "Mater Terra” egy "nomád” fesztivál, minden évben új helyszínre, új önkormányzati régióba költözik, hogy minél több helybeli közösséget aktivizáljon.
\end{abstract}

\section{ABSTRACT}

"Ecology and the ecology of the soul" was the focal issue of an educational innovation project in the performing arts. The project was realised in the last three years in drama education workshops and school based drama groups in the "Mater Terra" Children and Youth Festival in Serbia. "The ecology of the soul" is an educational method that is aimed at the continuous development of the personality, self-reflection and collaboration with peers. The central issue of our pedagogical efforts is: "Do we listen to our children? Or more concretely: do we listen to the future?" How can we prepare for challenges and professions that we, educators, have no idea about?

Basic life skills defined by the European Commission in 2016 involve critical thinking, motivation for asking questions and conducting research, sharing ideas and presenting results to 
others. For me, theatre and drama is the test of the future. Our expert group that consists of drama educators, psychologists, performers, and actors, put together a detailed manual based on workshop results, for drama teachers on how to develop the work of their drama and theatre groups. "Mater Terra", a nomadic festival, is moving from one region to the other each year in order to activate more and more local communities to integrate drama in education.

Kulcsszavak: drámapedagógia, színházi nevelés, művészetalapú kutatás

Keywords: drama education, theatre education, arts-based research

„Az ökológia és a lélek ökológiája” volt a témája annak az előadó-mủvészeti projektnek, amelyet alkotói csoportom szervezésében az elmúlt három évben drámapedagógiai mühelyek és iskolai drámacsoportok valósítottak meg a szerbiai „Mater Terra” Gyermek és Ifjúsági Színházi Fesztiválokon „A lélek ökológiája” a munkacsoport megfogalmazásában folyamatos személyiségfejlödés, önmegismerés és a társakkal való együttmüködés képességének fejlesztése. Előadómüvészként egész pályafutásom során azt a színházat részesítettem előnyben, amely kérdéseket vet fel, provokál és aktivizál, és nem azt, amelyik tényekkel szembesít, vagy csak visszatükrözi a valóságot. Ebben az esszében ugyanezt az elvet követem.

Pedagógiai munkánk egyik fő kérdése: „Meghallgatjuk-e a gyermekeinket?” Konkrétabban: „Meghallgatjuk-e a jövőt?” Hogyan tudnánk felkészíteni őket az olyan kihívásokra és szakmákra, amelyeket még mi magunk sem ismerünk? Az innovatív munkákhoz szükséges képességek az Európai Bizottság (European Commission, 2016) szerint a következők: kritikus gondolkodás, hajlandóság a kutatásra, kérdésfeltevésre és a tervek, ötletek bemutatására. Számomra a színház és a dráma a jövő próbája. Ez volt a címe az IDEA (International Drama \& Theatre in Education Association) 25. évfordulós ünnepi rendezvénye egyik eseményének is, 2017 júniusában. Az IDEA körülbelül nyolcvan olyan szervezetet számlál a világ minden tájáról, amelyek drámával, színház-pedagógiával és színházi neveléssel foglakoznak. Tanulunk egymástól, együtt fejlődünk, és ami nagyon fontos, első kézből nyerünk betekintést arról, hogy mi a helyzet a dráma- és színházi neveléssel a világon. A szervezet tagjai összehasonlító pedagógiai kutatásokkal, jó gyakorlatok közreadásával jelzik az oktatási döntéshozók felé a dráma- és színház-pedagógia jelentőségét és ígéretes irányait (DICE Consortium, 2010).

A dráma- és színház-pedagógia jelentősége a kinetikus, affektív és kognitív szféra közötti kapcsolatok kiépítése. Napjainkban, amikor az iskola elsősorban a gondolkodást fejleszti, különösen fontos a testtudat, a tudatos mozgásos kommunikáció megismertetése a fiatalokkal. Az elme és a test közötti kapcsolatot, az alkotást és önkifejezést integráló dráma és tánc a vizuális-térbeli képesség- 
csoportra épít. A mozgást középpontba helyezö, úgynevezett fizikai szinházban és a táncban olyan képességeket sajátíthatunk el, amelyek alapvetőek az emberi életben (Leavy, 2015, 155-159.). Minél több tánc-, dráma- és színház-pedagógiai módszer épül be a tantervekbe, annál sokoldalúbb lesz a gyermekek és a fiatalok felkészítése a jövőre. A japán harcmúvészetekben megtalálható a Sin-Gi-Tai koncepciója (Clarke, 2011), ami azt jelenti, hogy a tökéletes harcosnak fejlesztenie kell a testét, az elméjét és a lelkét is. Erősnek, rugalmasnak és hajlékonynak kell lenniük mind testben, mind elmében, mind lélekben.

Dráma- és színház-pedagógiai módszereink esszenciája megtalálható három szóban: kíváncsiság, kreativitás és együttérzés (curiosity, creativity, compassion). A kíváncsiság és a kreativitás a tanárral és a társakkal együtt megvalósított alkotó folyamatot jelenti. Ez az együttműködés megengedi a hibákat és ballépéseket, miközben olyan új lehetőségeket és tereket nyit, amelyeknek a létezéséről korábban semmit sem tudtunk. Miközben próbálunk, hibákat vétünk, és ezek gyakran új utakat és lehetöségeket nyitnak meg elöttünk. A színházban van erre egy kifejezésünk: örömteli hiba. Ezek a tévutak értékes tévedések - gyakran az előadás minősége múlhat rajtuk. A harmadik, pedagógiai módszereinket meghatározó minőség, az együttérzés, a versengés helyett a társak támogatását jelenti (O’Connor et al., 2003).

Amikor lefektettem a „Mater Terra” Fesztivál elveit és múködési módjait, úgy döntöttem, nem veszem alapul a már létező szerbiai drámapedagógiai fesztiválok sémáját. A mi fesztiválunk fő célja a szolidaritás fejlesztése, a kommunikáció és egymás munkájának kritikus elemzése lett. Az előadások tematikus blokkokba voltak rendezve, és a résztvevők megnézhették a többiek munkáját is. Ezután mühelymunka következett, ahol az előadásokban szereplő fiatalok drámatanáraikkal, a szülőkkel, nézőkkel, a szakértő csoportokkal vitathatták meg az alkotói folyamatot és a munka közben felmerült problémákat.

A kiemelkedő drámatanárokból, előadóművészekből, pszichológusokból álló szakértői csoport a mühelymunkák tapasztalataira alapozva részletes visszajelzést fogalmazott meg a drámapedagógiai alkotó közösségek vezetőinek arról, milyen irányban érdemes továbbfejleszteni csoportjukat. A „Mater Terra” egy „nomád” fesztivál, minden évben új helyszínre, önkormányzati régióba költözik, hogy minél több helybeli közösséget aktivizáljon.

A sportoktól eltérően, ahol az edzői utasítások minél tökéletesebb megvalósítása és minél jobb eredmény elérése a cél, nekünk, művészetpedagógusoknak a tökéletlenség tanításával is foglalkoznunk kell. A müvészet a kereső, változó, sebezhető, törékeny emberi lélekből, az alkotó tökéletlenségeiből ered. Minél tökéletesebbek vagyunk, annál jobban hasonlítunk a szabályvezérelt robotokra. Minél tökéletlenebbek, kiszámíthatatlanabbak, törékenyebbek, szabálytalanabbak vagyunk, annál emberibben müködünk. 
A színházcsinálás, színháztanítás alkotó folyamatának, különösen a kortárs színházénak, komplex szerepe van a fiatalok életében. Az eszköztár, amellyel rendelkeznek, a saját lényük, testük, hangjuk.

Az általam vezetett Drámapedagógiai és Mủvészeti Központ (Center for Drama in Education and Art, CEDEUM) az első szervezetek között volt, amely részt vett a DICE projektben (DICE, 2010). Ez a kutatás tizenkét országban dolgozó, a színház- és drámapedagógia (educational theatre and drama) eszköztárát használó partnereket tömörített. A kutatás célja az volt, hogy lássuk, hogyan hat a színház- és drámapedagógia az Európai Közösség által megfogalmazott nyolc kulcskompetencia (European Commission, 2006) közül ötre: az anyanyelvi kommunikációra; a tanulás módszereinek elsajátítására (a tanulás tanulása), a személyközi, az interkulturális, szociális és az állampolgári kompetenciára, a kezdeményezőkészségre (vállalkozói kompetencia) és a kulturális kifejezőkészségre. Az összehasonlító pedagógiai kutatás bebizonyította, hogy a színház- és drámapedagógia az élethosszig tartó tanulásnak is kiváló eszköze. A projekt legfontosabb eredménye, hogy egy újabbal gazdagította a fejlesztett kompetenciák sorát, az univerzális kompetenciáját annak, hogy mit jelent embernek lenni:

„Ez a kompetencia magában foglalja a másik ötöt, és egy új dimenzióval is bővül, mivel arra az egyetemes kompetenciára vonatkozik, hogy mit is jelent embernek lenni. A társadalmi összetartozásra és a fejlődő demokráciában való polgári létre irányuló egyre növekvő figyelem közepette olyan morális iránytüre van szükségünk, melynek segítségével megtalálhatjuk helyünket és egymás helyét a világban, és elkezdhetjük újragondolni meglévő értékeinket, sőt új értékeket hozhatunk létre. Ki kell találnunk és el kell képzelnünk egy olyan társadalmat, amelyben érdemes élni, ahol jobban érzékeljük, merre is tartunk, és meggyőződéssel tudjuk, hogy milyen emberekké akarunk válni” (DICE Consortium, 2010, 20.).

A színház- és drámapedagógia sokoldalú képességfejlesztő hatását igazoló legutóbbi nemzetközi projektünk színhelye egy norvég iskolában, a sandnesi Vågen Gimnázium ultramodern és kiváló technikai felszereltségủ épületében volt. Az iskolában mintegy 800 diák tanul különböző tagozatokon. Évente egyszer a tagozatok összegyűlnek, hogy együtt hozzanak létre egy közös „összművészeti alkotást”. Kísérletünk idején, 2016-ban ez egy musical volt, amely nemcsak az egyik legkomplexebb és legigényesebb müvészeti forma, de ráadásul olyan integratív müfaj, amely egyesíti magában a vizuális müvészeteket (díszlet- és jelmeztervezés, a világítás és az előadással kapcsolatos grafikai anyagok megtervezése), a megkomponált és előadott zenét és táncot, az éneklést és a színjátszást. Az előadás az iskola összes tanulójának részvételével valósult meg, a nézők pedig a sandnesi és a közeli stavangeri polgárok voltak. A tanárok és a diákok szorosan együttmüködve, professzionális szinten dolgoznak a kortárs építőmüvészet remekének számító iskolaépületben. A vizuális és zenei nevelés mellett a dráma-, 
színház- és tánctanulmányok eredményei egyszerre, egy közösségi alkotás keretében váltak érzékelhetôvé, amelyek a részt vevő diákok számára a művészeti ágak közötti kapcsolódási pontokat is átélhetővé és megérthetővé tették.

Ezt a kapcsolatrendszert erősíti a Müvészetpedagógiai Világszervezet, a World Alliance for Arts Education (WAAE), a társmüvészetek szövetségeit összefogó bizottság, amely a tánc- és drámapedagógiai és a zenei nevelés fontosságára hívja fel az oktatási döntéshozók figyelmét. Ettől az együttműködéstől is várjuk a müvészetek iskolai szerepének megerősítését, közös fejlesztési céljaink hatásosabb megvalósulását.

\section{IRODALOM}

Clarke, G. (2011): Shin Gi Tai: Karate Training for Body, Mind, and Spirit. Wolfeboro, New Hampshire: YMAA Publication Center, Inc.

DICE Consortium (2010): Making a World of Difference - A DICE Resource for Practitioners on Educational Theatre and Drama. http://www.dramanetwork.eu/file/Education\%20Resource\%20long.pdf (utolsó letöltés: 2017. 09. 24.) Magyarul: Kutatási eredmények és ajánlások a tanítási színház és dráma alkalmazásával kapcsolatban. http://www.dramanetwork.eu/file/ DICE_kutatasi_eredmenyek.pdf

European Commission (2016): The Future of Work. Skills and Resilience for a World of Change. Paris: European Political Strategy Centre, https://ec.europa.eu/epsc/sites/epsc/files/strategic note_issue_13.pdf (utolsó letöltés: 2017. 09. 24.)

Leavy, P. (2015): Method Meets Art. Arts-Based Research Practice. $2^{\text {nd }}$ edition. New York-London: The Guilford Press

O'Connor, P. - Szauder E. - Bentsen, E. (2003): Partnership, Protection and Participation: Principles for Working in Drama with People with Special Needs. In: Heikkinen, H. (ed.): Special Interest Fields of Drama, Theatre and Education. Jyväskylä: Jyväskylä University Press, 54-65.

URL1: http://www.hlebteatar.com/

URL2: https://ideadrama.org/

URL3: http://cedeum.org/en/about

URL4: https://www.isme.org/

URL5: http://www.worlddancealliance.org/

URL6: http://waae.edcp.educ.ubc.ca/

URL7: http://www.insea.org/ 